\title{
THE IMPLEMENTATION OF COOPERATIVE PRINCIPLE IN CLASS GROUP DISCUSSION
}

\author{
Dase Erwin Juansah', Emzir ${ }^{2}$ \\ ${ }^{1}$ Universitas Negeri Tirtayasa Serang, Indonesia \\ ${ }^{2}$ University Negeri Jakarta, Indonesia \\ 2emzir@gmail.com
}

\begin{abstract}
This study is aimed to understand the implementation of Grice's cooperative principle in class group discussion at Indonesian Language and Literature Study Program of Faculty of Teachers Training and Education of UNTIRTA Serang. The research was conducted through ethnographic study. Data of the research were collected through observation and transcription of documentation which investigated into the analysis of domain, taxonomy, componential, and cultural themes. The result of study showed that the implementation of Grice's cooperative principles was found in class group discussion at Indonesian Language and Literature Study Program of Faculty of Teachers Training and Education of UNTIRTA Serang. The maxim that mostly occurred was maxim of quantity, continued by maxim of relevance, maxim of quality, and maxim of manner. The result also showed that the use of cooperative principles in class group discussion could not be separated from the influence of students' origin culture and mother tongue which reflected into the use of formal language, politeness, tone, sense of respect and focus on the discussion, and the use direct speech.
\end{abstract}

Keywords: cooperative principle; class group discussion; ethnographic study.

Commonly, the students of Indonesian Language and Literature Study Program of Faculty of Teachers Training and Education of UNTIRTA Serang come from different origin culture and mother tongue. They are not only come from Banten area, but also from other areas such as West Java, Jakarta, Sumatra, and Kalimantan. These circumstances, of course, affect the use of language inside and outside of the classrooms.

Based on the writer's pre-observation, most of students could not deliver their idea briefly and orderly due to their lack understanding on the topic of the discussion. Since this condition related to the cooperative principle, it seems that the students are violating the maxims. Besides, the students also seem to have lack of knowledge and understanding to whom they are speaking. This result shows that the students have wrong decisions in using style of language, body language, and accent.

Based on the above introduction, it can be concluded that the communicative competence has an essential part in encouraging students to use the style of language due to its contexts of utterance. Therefore, these conditions urge the writer to analyze the use of cooperative principle in class group discussion.

In ordinary communication, it can be assumed that a speaker articulates an utterance to communicate something to addressee in order that his addressee may know the point of the communication (Wijana dan Rohmadi, 2009:41-42). This means that the speaker has to try to make his utterance relates to its context, brief, clear, orderly, understandable, and focus on the point of the communication. Sometimes, it is also obvious that communication does run well at all. There are always certain implications pointed by the speaker. If it does not exist, the speaker 
seems to uncooperative. Thus, it simply assumed that there is some kind of cooperative principle hold by the speaker and addressee to assure the process of communication may run well.

The conversational exchange seems to be that the participant are cooperating each other (Grice, 1995: 26-27). This cooperative principle divided into maxim of quantity, quality, relation, and manner.

a. The Maxim of Quantity, It refers to the given quantity of information; (1) make your contribution as informative as is required, (2) no more or less. b. The Maxim of Quality It is often called as super maxim; (1) do not say that you believe to be false, (2) for which you lack evidence. c.The Maxim of Relation Be relevant; focus on the topic of communication, how to turn taking and takes part. d. The Maxim of Manner It is often called as super maxim; be clear, brief, and orderly.

In Grice theory, communication could happen indirectly through convention (Rahardi, 2004: 24). In this case, the speaker wants his addressee to recognize his intention, and how the speaker exploits the cooperative principles through certain utterances and contexts.

Based on the above theories, it can be concluded that Grice's cooperative principle intended to lead the process of communication among speakers and addressees run well. If this condition related to the process of discussion among Indonesian Language and Literature students, it is hoped that they can perform discussion in line with the maxims in cooperative principle.

In common, this study is aimed to understand the implementation of speech acts in class group discussion at Indonesian Language and Literature Study Program of Faculty of Teachers Training and Education of UNTIRTA Serang. Specifically, this study is aimed to understand the implementation of Grice's cooperative principle in class group discussion at Indonesian Language and Literature Study Program of Faculty of Teachers Training and Education of UNTIRTA Serang.

\section{METHOD}

As already stated above, this study is aimed to understand the implementation of Grice's cooperative principle in class group discussion at Indonesian Language and Literature Study Program of Faculty of Teachers Training and Education of UNTIRTA Serang. The research is conducted through qualitative approach by using ethnographic study (Emzir, 2007: 28-29). Data of the research were collected through observation and transcription of documentation. The data, then, are analyzed through the analysis of domain, taxonomy, componential, and cultural themes (Emzir, 2007: 165-166). Meanwhile, data of the research itself are obtained from lecturer and students' speech acts in class group discussion.

\section{RESULTS}

Based on the data analysis of the implementation of Grice's cooperative principle in class group discussion at Indonesian Language and Literature Study Program of Faculty of Teachers Training and Education of UNTIRTA Serang, it can be shown as follow. 
Table 1. The Implementation of Grice’s Cooperative Principle (First Recording)

\begin{tabular}{|c|c|c|c|c|}
\hline \multirow{2}{*}{ Dialogues } & \multicolumn{4}{|c|}{ The Implementation of Cooperative Principle } \\
\cline { 2 - 5 } & Quantity & Quality & Relation & Manner \\
\hline Dialogue & 10 & 7 & 8 & 6 \\
\hline Utterance & 33 & 20 & 33 & 15 \\
\hline
\end{tabular}

Based on the table 1 above, it can be explained that there are 10 dialogues with 33 utterances of quantity maxim, 7 dialogues with 20 utterances of quality maxim, 8 dialogues with 33 utterances of relation maxim, and 6 dialogues with 15 utterances of manner maxim. Thus, it can be concluded that both of lecturer and students' had already understood and applied the cooperative principle in class group discussion.

Table 2. The Implementation of Grice’s Cooperative Principle (Second Recording)

\begin{tabular}{|c|c|c|c|c|}
\hline \multirow{2}{*}{ Dialogues } & \multicolumn{4}{|c|}{ The Implementation of Cooperative Principle } \\
\cline { 2 - 5 } & Quantity & Quantity & Quantity & Quantity \\
\hline Dialogue & 12 & 11 & 10 & 8 \\
\hline Utterance & 43 & 37 & 35 & 32 \\
\hline
\end{tabular}

Based on the table 2 above, it can be seen that there are 12 dialogues with 43 utterances of quantity maxim, 11 dialogues with 37 utterances of quality maxim, 10 dialogues with 35 utterances of relation maxim, and 8 dialogues with 32 utterances of manner maxim. Therefore, it also concluded that both of lecturer and students' had already understood and applied the cooperative principle in class group discussion.

Based on the result of research for both of table 1 and 2, it can be concluded that class group discussion activities done by Indonesian Language and Literature students of Faculty of Teachers Training and Education of UNTIRTA Serang had applied the cooperative principle included of all maxims.

If it is seen in quantity maxim, the group discussion done by the students have showed that they make their contribution as informative as is required, no more or less. Then, in quality maxim, it can be also showed that both of speakers and addresses have said the utterances that they believe to be true with available evidence.

\section{DISCUSSION}

In the process of discussion, all of students have focused on the topic of the discussion, thus, their questions and answers put in line with the topic. The questions and answers also held clearly and briefly, without any ambiguity.

The data analysis shows that several utterances imply more that one maxim, and it also proves the common utterances apply quantity maxim, followed by relation, quality, and manner maxims.

Based on the above discussion, it can be concluded that class group discussion done by the lecturer and students have contributed as informative as required. It is absolutely clear that they have operated quantity maxim. All of students also focus on the topic of the discussion through delivering questions and answers related to the topic. Besides, it can be also showed that both of lecturer and students have said the 
utterances that they believe to be true with available evidence. Of course, this means that they have operated quality maxim. The last, process of discussion also held clearly, briefly, and without any ambiguity.

In line with the above result, the research finding and discussion can be seen as follow.

1) The Implementation of Quantity Maxim in Class Group Discussion

The basic principle of quantity maxim is to make your contribution as informative as is required, no more or less. The result of the research shows that both of the speakers and addressee have contributed as informative as is required. Besides, the result also shows that quantity maxim is the major maxim implemented in the class group discussion.

2) The Implementation of Quality Maxim in Class Group Discussion

The result of the research also shows that the class group discussion have operated the quality maxim. As already stated that quality maxim means to not say that you believe to be false, or for which you lack evidence. This means that both of speakers and addresses in class group discussion have delivered information that they believe to be true with available evidence.

3) The Implementation of Relation Maxim in Class Group Discussion

Relation maxim means be relevant, focus on the topic of communication, how to turn taking and takes part. In line with the theory, the research shows that in the process of discussion, all of students have focused on the topic of the discussion, and their questions and answers correspond to the topic.

4) The Implementation of Manner Maxim in Class Group Discussion

Students' communicative competence and activities of reading related references have obviously affected their competences in formulating ideas and arguments in oral or written. This absolutely proves that the students can formulate the questions and answers clearly, briefly, and without any ambiguity.

As already stated previously, the students of Indonesian Language and Literature Study Program of Faculty of Teachers Training and Education of UNTIRTA commonly come from Banten province, especially from areas of Lebak, Pandeglang, Tangerang, and half of Serang use Sunda Language as mother tongue. Meanwhile, other areas such Cilegon and half of Serang use Java Language, and Tangerang Selatan use Indonesian Language.

Seemingly, the students' mother tongues influence or interference their first language, in this case Indonesian Language, in their communication process at inside and outside of the class. This interference may occur at the word and even sentence units. When a student comes from Lebak or Pandeglang areas, for instance, they usually use Sundanese particle such 'mah' or 'teh' in their conversation. The students from Tangerang area commonly use informal words such 'kemane', 'dimane', or 'kagak.' Meanwhile, the students from Cilegon and Serang areas commonly use Javanese particle such 'tah', 'geh,' or 'oj.'

In common, Banten people have culture that reflected in language ethics. When they communicate, whether written or oral, they will use language variety, known as Undak Usuk Bahasa in Sunda and Bebasan in Java, based on the addressee and the context given.

The speech acts in class group discussion at Indonesian Language and Literature Study Program of Faculty of Teachers Training and Education of UNTIRTA show that the students have highly focus and sense of respect. This, of course, reflected in 
the implementation of cooperative principle by operating all of the maxims. In other words, students' focus and sense of the respect manifested through the maxims. Besides, two-ways interaction among speakers and addresses also occurred in the discussion. This shows students' appreciation and attention towards the discussion. The students also deliver the information based on the factual truth. Therefore, it can be concluded that class group discussion done with highly focus and sense of respect, involving two-ways interaction, and showing students' appreciation and attention towards the discussion.

\section{CONCLUSION}

In common, the result of research concludes that class group discussion at Indonesian Language and Literature Study Program of Faculty of Teachers Training and Education of UNTIRTA have operated the cooperative principles even though some students have violated the maxims. This occurred due to the students' misconception and misunderstanding about the maxims, and they seem to have a joke while discussing.

In correspond to the above result; there are several recommendations as follow. First, the students' should improve their own understanding in term of the cooperative principle, so they may minimize violating the maxims and friction among them. Second, the students and the lecturer at Indonesian Language and Literature Study Program of Faculty of Teachers Training and Education of UNTIRTA should use Indonesian Language correctly, and next to be contextually, so that they can be a model for all of students in UNTIRTA. Besides, the lecturer needs to strengthen the use of cooperative principle to his students by communication process inside and outside of the classroom as an effort to minimize violating the maxims. This absolutely gives the students contribution for communicating formally and informally. Third, other researchers may apply the further study that focused on pragmatics in class group discussion, such as implicature, politeness, and entailment. Fourth, all authors of Indonesia Language text book of elementary till university level, should focus on language skill of speaking. This, of course, intended to aid students to communicate correctly.

To all lecturers should avail a lot of chances to his/her students to communicate in class group discussion because it is found that many students have lack competences in conveying their ideas and opinions. Therefore, the writer concludes and agrees that communicative competence use in conveying ideas and opinions is the matter of habits.

\section{REFERENCES}

Emzir. (2007). Metodologi Penelitian Pendidikan. Jakarta: PT. Rajagrafindo Persada.

Grice, H. Paul. (1975). Logic and Conversation, in Syntax and Semantics, Volume 3 Editor John P Kimball. New York: Academic Press. 
Grice, Paul. (1995). Studies in the Way of Words: Fourth Printing. Cambridge: Harvard University Press.

Rahardi, Kunjana. (2004). Berkenalan dengan Ilmu Bahasa Pragmatik. Malang: Dioma.

Wijana, I Dewa Putu. (2009). Analsis Wacana Pragmatik. Surakarta: Yuma Pustaka.

Wijana, I Dewa Putu dan Muhamad Rohmadi. (2009). Analisis Wacana Pragmatik: Kajian Teori dan Analisis. Surakarta: Yuma Pustaka. 